1 Title: Exploring the Agricultural Reutilisation of Desalination Reject Brine from Reverse

2 Osmosis Technology

3 Authors \& affiliations:

4 David Jiménez-Arias ${ }^{\mathrm{a}^{*}}$, Sarai Morales Sierra ${ }^{\mathrm{b}}$, Fráncisco J. García-Machado ${ }^{\mathrm{a}}$, Ana L. García-

5 García $^{\mathrm{a}}$, Andrés A. Borges ${ }^{\mathrm{a}}$, Juan C. Luis ${ }^{\mathrm{b}}$.

6 a Chemical Plant Defence Activators Group, Department of Agrobiology, IPNA-CSIC, Avda.

7 Astrofísico Francisco Sánchez 3, P.O. Box 195, 38206 La Laguna, Tenerife, Canary Islands,

8 Spain

9 b Grupo de Biología Vegetal Aplicada (GBVA), Departamento de Botánica, Ecología y 10 Fisiología Vegetal - Facultad de Farmacia, Universidad de La Laguna, Avda. Astrofísico

11 Francisco Sánchez s/n, 38071 La Laguna, Tenerife, Canary Islands, Spain

12 *Corresponding author: David.j.a1983@ gmail.com

13 Keywords: Reject brine; Desalination; Circular economy; Hydroponic; Horticulture;

14 Floriculture

15 Highlights

16 1. Reject brine is a constant and reliable source of minerals that can be used as a raw material in

17 hydroponic culture.

18 2. Brines analysed in various countries have a rich content of plant nutrients, showing the

19 feasibility of using brine salts within the agricultural context.

20 3. A circular economy based on sustainable brine management offers reduced crop production

21 costs using a hydroponic facility, along with possible further secondary incomes.

\title{
22 Abstract
}

23 Among its other effects, climate change is driving humanity into water scarcity, especially in

24 highly populated areas such as the Mediterranean. One of the best options to solve this problem

25 is seawater desalination, but it has its environmental, social and economic impacts. The brine

26 reject effluent from the process can be used as a rich mineral source for hydroponic culture.

27 Indeed, stability in its composition was shown here during a one-year study. A compilation of 
analyses from desalination facilities located worldwide also demonstrates how reutilisation of

29 this liquid waste can provide an opportunity to build a circular economy based on brine

30 management. Potential profitable crops and an economic study of its implementation are

31 discussed. Correct brine management channelled into an agricultural context can be an excellent

32 way to improve the public and ecological reputation of desalination. It can also yield extra

33 income beyond the fresh water yield from the proposed system.

34 1. Introduction

35 Intense industrialisation and high urbanisation rates combined with climate change are the main 36 contributors to the water crisis affecting many parts of the planet [1], while agriculture consumes

37 approximately $60 \%$ of available water resources in developed countries [2]. Worldwide, from

381983 to 2009, 454 million cultivated hectares suffered yield reductions due to drought problems,

39 causing losses that could reach $143 €$ billion [3]. Lack of fresh water is acutely worrying in

40 Europe and even more dramatic in the Mediterranean area, where its availability is expected to

41 again reach levels below those of 1990 [4]. The rest of the world will likely follow a similar

42 trend, with estimations of severe water scarcity in more than 60 countries [5]. In the 21 st century,

43 this disturbing scenario has caused the emergence and development of new technologies to

44 obtain fresh water. The most encouraging method is desalination [6].

45 Desalination capacity has been increasing by $7 \%$ on average per year [7], reaching 97.2 million $46 \mathrm{~m}^{3} /$ day [8]. The most widely used feed source is seawater, $58.9 \%$, followed by brackish 47 groundwater (21.2\%) [6]. More than 20 different technologies are used nowadays for seawater 48 desalination, however Reverse Osmosis is the most widely used in small and medium facilities, 49 covering $69 \%$ of the installed water desalination capacity [9], so it will be focused on here. Brine 50 from seawater desalination is one of the most promising sources of fresh water for securing the 51 global water supply [10]. It offers significant advantages when compared with other sources, 52 owing to its sustainable supply. However, a debate about the environmental costs of desalination 53 is emerging in society nowadays [11-13], focused on more careful brine management and 54 reducing the high energy costs of running the facilities, which are factors limiting its expansion 55 [8,11-14]. Social acceptance is one of the most common problems when a new facility is to be 56 established near urban areas [15]. However, the too-frequent "not in my backyard" way of 
57 thinking is not sustainable [16]. It is therefore necessary to look for new strategies to overcome 58 or assuage the prevalent opinion and gain public acceptance.

59 Brine production was estimated at 141.5 million $\mathrm{m}^{3} / \mathrm{day}$ in 2019 [8], and several studies have 60 described how coastal brine discharge affects benthic ecosystems [17-20]. Alternatives to reduce 61 brine impacts explore dilution, mixing, diffusion jets and their drastic reduction using minimum62 and zero-liquid discharge approaches [21]. However, applying this technology in practice 63 requires more feasibility studies [22]. In addition, the quantity of surplus brine itself has inspired 64 researchers to work towards different ways of transforming this otherwise contaminant waste 65 product into a useful resource. Many studies have tried to use brine as a source of valuable 66 elements [23], and the authors calculated appreciable revenues from what they call "seawater 67 mining" to offset the cost of the desalination process. Sodium hydroxide can be produced using seawater brine as a source [24], or greenhouses can be cooled by evaporating it, obtaining salt in

69 the process [25]. Brine can be used for halophytic crops by soil irrigation [26], but it has 70 deleterious effects over time. These lead to soil degradation and consequent yield losses in later 71 non-halophytic plants [27], which prevent this type of application in most cases. Finally, other 72 studies point out the potential of using brines in fish farming, spirulina cultivation, and irrigating 73 forage shrubs [28], and also to produce $\beta$-carotene [29]. These projects open exciting new 74 avenues for direct brine utilisation.

75 Previous work [30] demonstrated that, with simple modifications, reject brine can be used as a 76 nutritive solution for crop production in a hydroponic system. As a bonus, fruits produced in this 77 way had better organoleptic parameters after growth under saline conditions. Consequently, soilless agriculture and horticulture should be considered as alternative reuse channels for part of this brine, as it has significant advantages over traditional cultivation methods. For instance: i) 80 sites can be located near desalination facilities, avoiding the problem of low availability of 81 agricultural land [31,32], ii) this also avoids soil degradation by brine due to its excessive ionic 82 content [27], iii) brine minerals can be used to reduce the quantity of nutrients needed to produce 83 a balanced complete hydroponic solution [30]. As mentioned before, reject seawater brine 84 contains considerable amounts of minerals essential for plant growth, such as $\mathrm{Ca}^{2+}, \mathrm{Mg}^{2+}$, and $85 \mathrm{~K}^{+}$, commonly known as macronutrients [30]. Use of brine in hydroponic systems installed near 86 desalination facilities can yield other profitable benefits and savings. Several by-products with 
87 agricultural and horticultural uses can be manufactured from it, as an attractive way to generate new income and also enhance public acceptance of this technology [33,34].

89 This study focuses on reutilising the desalination brine from Reverse Osmosis facilities. With

90 this end, a one-year asssessment is presented here of five desalination facilities on Tenerife (the

91 largest of the Canary Islands). It shows how reject brine can be a constant and excellent source of

92 minerals to feed hydroponic facilities. Furthermore, the potential international implementation of

93 this approach is supported by analyses of brine effluent from reverse osmosis desalination

94 facilities in mainland Spain, published data from several countries, and the nutritional

95 requirements of different crops.

96 2. Material and methods

$97 \quad 2.1$ Reject seawater brine samples

98 Sample acquisition from Tenerife began in November 2019 and concluded in November 2020.

99 The local brine samples came from 5 reverse-osmosis desalination facilities around the island.

100 The second set of samples from two facilities in the Mediterranean was received in August 2020.

101

102

103 Table 1. Desalination facilities used in the study

\begin{tabular}{ccc}
$\begin{array}{c}\text { Desalination } \\
\text { facility }\end{array}$ & Production & Location \\
\hline A & $4000 \mathrm{~m}^{3} /$ day & Urban zone \\
B & $500 \mathrm{~m}^{3} /$ day & Urban zone \\
C & $4000 \mathrm{~m}^{3} /$ day & Agricultural zone \\
D & $1800 \mathrm{~m}^{3} /$ day & Agricultural zone \\
E & $5000 \mathrm{~m}^{3} /$ day & Agricultural zone \\
Alicante & $65000 \mathrm{~m}^{3} /$ day & Urban zone \\
Murcia & $57000 \mathrm{~m}^{3} /$ day & Urban zone
\end{tabular}

104

$105 \quad 2.2$ Reject brine analyses

106 A total of 180 samples from Tenerife were analysed in triplicate. One replicate from each 107 desalination facility was taken from the Mediterranean samples. Macronutrients $\left(\mathrm{Ca}^{2+}, \mathrm{K}^{+}\right.$and $\left.108 \mathrm{Mg}^{2+}\right)$, sodium, micronutrients $(\mathrm{Cu}, \mathrm{Mn}, \mathrm{Fe}$ and $\mathrm{B}$ ) and heavy metals ( $\mathrm{As}, \mathrm{Hg}, \mathrm{Cd}$ and $\mathrm{Ni}$ ) were 109 quantified using an ICP-OES AVIO500 (Perkin Elmer). For anions $\left(\mathrm{Cl}^{-}, \mathrm{NO}_{3}{ }^{-}, \mathrm{PO}_{4}^{-3}, \mathrm{SO}_{4}{ }^{-2}\right)$ the 110 ionic chromatographer 883 Basic IC plus (Metrohm AG) was used, fitted with a Metrosep A, 
111 Supp. 5 250/4 mm column (Metrohm AG). The mobile phases were water/ $\mathrm{H}_{2} \mathrm{SO}_{4} 100 \mathrm{mM}$ and

$112 \mathrm{Na}_{2} \mathrm{CO}_{3} / \mathrm{NaHCO}_{3} 3.2 \mathrm{mM}$ and $1 \mathrm{mM}$, respectively.

$113 \quad 2.3$ Reject brine transformation

114 The transformation began by comparing the brine chemical composition with Hoagland's 115 standard nutrient solution[35]. A series of dilutions were necessary to reduce specific toxic ion 116 levels $\left(\mathrm{Na}^{+}, \mathrm{Cl}^{-}\right.$and B). The selected dilution was transformed by specific amendments (listed in 117 tables 5,6 and supplementary 1 to 7), following the Nutrient Solution Calculator datasheet 118 provided by Incrocci (Dipartimento di Biologia delle Piante Agrarie, University of Pisa) to attain 119 Hoagland's nutrient content [35]. This transformed solution was assessed for its environmental 120 and economic costs and used in various agricultural and horticultural crops.

1212.4 Statistical procedures.

122 One-way ANOVA and a Tamhane post hoc test were applied to analyse the significance of 123 differences between experimental groups, using IBM-SPSS20 software.

125 3. Results and Discussion.

\subsection{Mineral analysis of local reject seawater brine. Location vs. time comparison.}

127 Reject brine analysis showed high macronutrient ion content, especially $\mathrm{Ca}^{2+}, \mathrm{K}^{+}, \mathrm{Mg}^{2+}$. Sodium 128 reached levels above $16 \mathrm{~g} \mathrm{~L}^{-1}$ in the brine; it is not considered a macronutrient but has a 129 significant effect on nutritive solution conductivity, to be discussed in the following sections. For 130 plants, inorganic salts dissolved in water are the primary source of mineral ions such as $\mathrm{Ca}^{2+}, \mathrm{K}^{+}$ 131 and $\mathrm{Mg}^{2+}$ [36]. These minerals play essential roles in plant growth, flowering and fruit 132 development, critical factors in crop production. Previous work in the present research line 133 showed how using reject brine was both an excellent source of macronutrients and a way to 134 reduce the cost of nutrient mineral solutions by $20 \%$, and also how to minimise productivity 135 losses due to high $\mathrm{Na}^{+}$levels in a commercial crop [30]. Each brine sample and results came 136 from a single desalination facility at a specific location at a particular time of year.

137 In order to establish if a constant supply of $\mathrm{Ca}^{2+}, \mathrm{K}^{+}$, and $\mathrm{Mg}^{2+}$ can be achieved all year round, 138 brine from five desalination facilities at different locations on the island of Tenerife was analysed monthly. The results showed $\mathrm{Ca}^{2+}$ concentration variations during the experimental period, from 
140350 to $750 \mathrm{ppm}$; however, values were similar in the five desalination plants studied (Figure1A).

141 It is interesting how its concentration fell in all studied facilities in November, reaching 142 minimum values in December, except for one where this minimum was in January. From these 143 minima, $\mathrm{Ca}^{2+}$ concentration rose to maximum levels in March-May, slowly falling again during 144 the following months until November, at all desalination facilities. However, one-year average $145 \mathrm{Ca}^{2+}$ concentration showed statistically non-significant differences between the different 146 locations (Figure 1B), always above $500 \mathrm{ppm}\left(12.1 \mathrm{mmol} \mathrm{L}^{-1}\right)$. These values were 22 times 147 higher than the concentration needed for a standard hydroponic solution like Hoagland's [35]. 148 Reject brine seems a reliable source of $\mathrm{Ca}^{2+}$, and showed no calcium-associated disorders in 149 tomato plants in previous work [30]. Calcium is considered one of the essential elements in plant 150 growth and development, also acting as a messenger in responses to biotic and abiotic stresses 151 [37]. It is moreover extremely important in post-harvest fruit quality [38]. Calcium disorders or 152 deficiencies cause many plant disorders, resulting in critical economic losses [39-41]. Clearly, a 153 correct and constant $\mathrm{Ca}^{2+}$ supply will enhance crop growth quality and defence, especially under 154 hydroponic systems $[42,43]$.
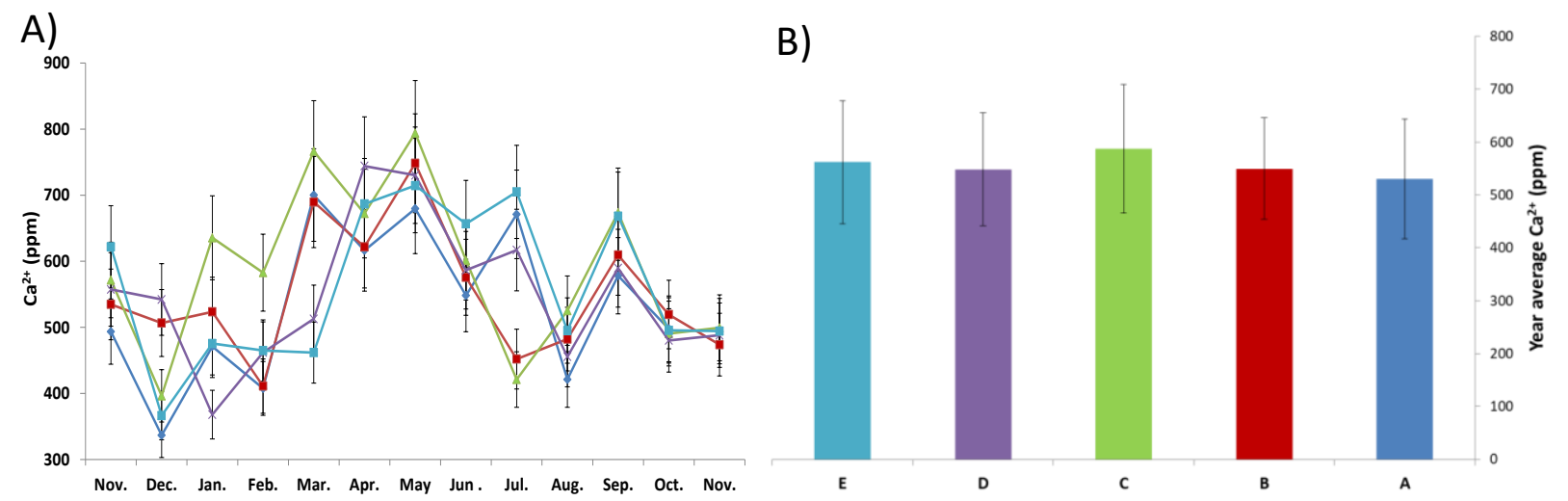

Figure 1. Seawater calcium analyses of brine from five desalination facilities on Tenerife. A) Monthly reject brine analysis during the one-year period. B) One-year concentration average 158 for each facility, listed with letters A to E.

160 Potassium showed higher concentrations compared to $\mathrm{Ca}^{2+}$ (Figure 2B). A minimum of $700 \mathrm{ppm}$ 161 and maximum $1050 \mathrm{ppm}$ concentrations were registered, according to desalination facility and 162 year. Despite these differences, average $\mathrm{K}^{+}$concentrations were always between 800 to $900 \mathrm{ppm}$ 163 at all facilities (Figure 2B). The exceptions were registered between February and May, when all 
164 the analyses showed an increase in $\mathrm{K}^{+}$concentrations, but only in three desalination facilities in 165 July (Figure 2A). It is noteworthy that the three facilities with the highest $\mathrm{K}^{+}$levels in July are next to vast banana plantations. In the May-July period, banana plants reach the fruit set period,

167 which requires higher nutritional elements, especially potassium, finishing at the end of July 168 [44]. This excess fertilisation could affect nearshore waters [45], resulting in a $\mathrm{K}^{+}$increase in the reject brine deriving from intake seawater. On average, $\mathrm{K}^{+}$concentrations in brine were $850 \mathrm{ppm}$

$170\left(22 \mathrm{mmol} \mathrm{L}^{-1}\right)$, ten times more than a regular Hoagland solution [35]. It is therefore a reliable and 171 demonstrated source of $\mathrm{K}^{+}$in crop production [30]. Potassium is essential in plant production, 172 and appropriate $\mathrm{K}^{+}$fertilization demonstrated reductions in yield losses [46]. Previous research 173 showed how $\mathrm{K}^{+}$deficiency limited water-use efficiency in economically important crops such as 174 wheat, maize or sugar beet [47], being critical in stomatal closure/aperture processes [48]. It also modulates responses against environmental stresses such as salinity, drought and metal toxicity

176 [49], affecting plant growth and metabolism, due to its involvement in carbohydrate and protein 177 biosynthesis, and enzyme activation [50].

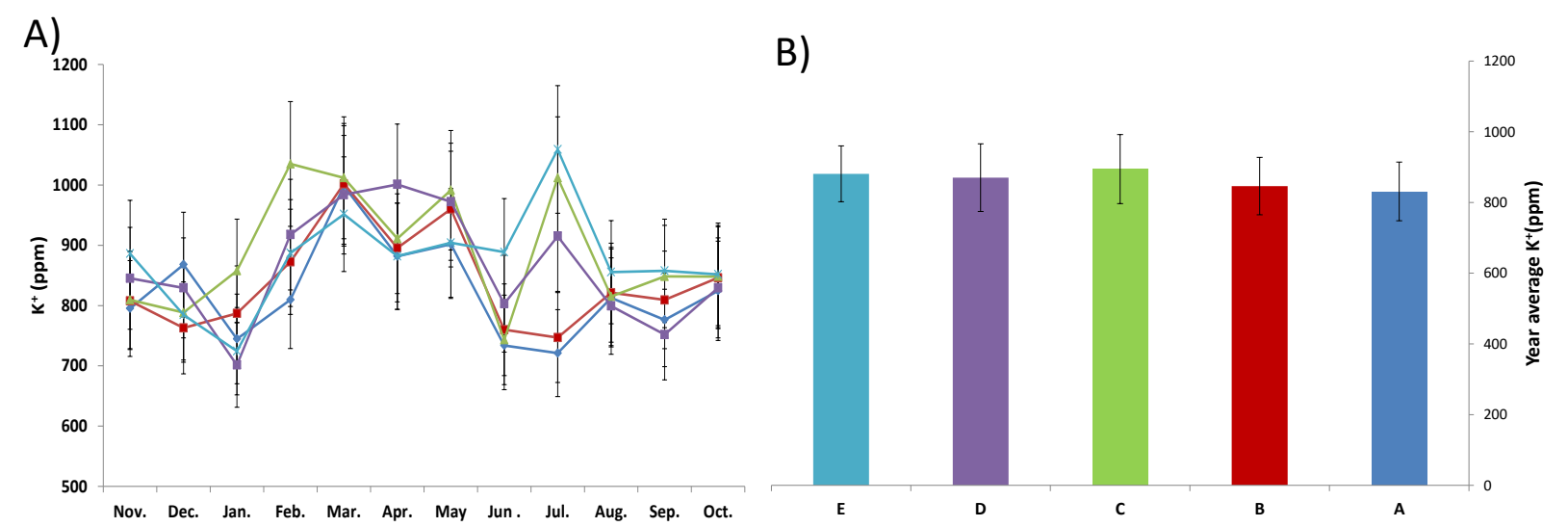

Figure 2. Potassium analyses of seawater brine from five desalination facilities on Tenerife. A) Monthly reject brine analysis results during the one-year period. B) One-year concentration average for each desalination facility, listed with letters A to E.

Magnesium had the highest concentrations of all macronutrients analysed in the reject brines (Figure 2A). It showed relatively constant levels during the twelve months monitored, with a significant increase in April and May (Figure 3A). Annual average levels were statistically nonsignificant between the facilities (Figure 3B), reaching values above $2000 \mathrm{ppm}\left(82.26 \mathrm{mmol} \mathrm{L}^{-1}\right)$. These $\mathrm{Mg}^{2+}$ concentrations enable a 40 times dilution of the reject brine, as demonstrated in previous work [30], enabling plant vegetative growth and fruit production without any 
189 deficiency. Magnesium plays a central role in the structure of the chlorophyll molecule, acting as 190 the pillar of photosynthetic activity [51]. It is involved in many enzyme activities, for example, 191 reactive oxygen species homoeostasis and structural tissue stabilisation [52]. However, beyond 192 the essential role of $\mathrm{Mg}^{2+}$ in plants, it is noteworthy that hypomagnesaemia is known to 193 contribute to several chronic human diseases [53]. Moreover, nearly two-thirds of the world 194 population does not consume the recommended amount of $\mathrm{Mg}$ [54]. This is probably because $195 \mathrm{Mg}^{2+}$ concentrations in food crops have decreased over time [55], for two main reasons: i) most 196 agricultural soils are acidic (about 70\%) and $\mathrm{Mg}^{2+}$ solubility decreases at low $\mathrm{pH}$ [56]; ii) 197 drought periods caused by climate change lower the amount of $\mathrm{Mg}^{2+}$ available for plants [57].

198 Consequently, seawater brines are a perfect source of enormous amounts of this mineral, easily 199 incorporated and accumulated by plants [30], to obtain crops with the recommended nutrient 200 concentrations for human health. Crop biofortification could become a future research field to 201 explore with brine contents.

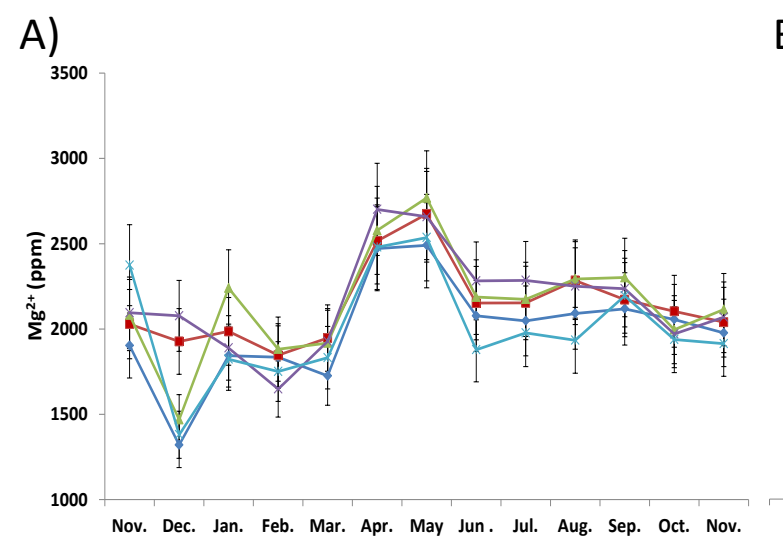

B)

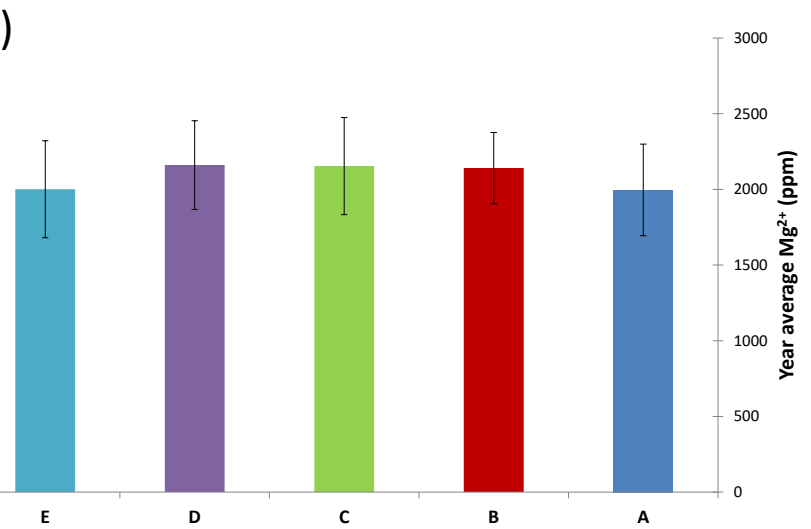

Figure 3. Magnesium analyses of seawater brine from five desalination facilities on

204 Tenerife. A) Monthly reject brine analysis during the one-year period. B) Annual concentration 205 average for each desalination facility, listed with letters A to E.

206 The analysis also showed higher amounts of the anion $\mathrm{Cl}^{-}$, reaching concentrations above $30 \mathrm{~g} / \mathrm{l}$ 207 and a total absence of carbonates. Table 2 summarises anion concentrations, notably high levels 208 of SO4 and low levels of other essential macronutrients, PO4 and NO3. These SO4 levels 209 together with the $\mathrm{Cl}^{-}$must be taken into account when preparing the final solution, preferentially 210 using nutrient $\mathrm{PO} 4$ and $\mathrm{NO} 3$ for the final amendments.

211 Table 2. One-year average anion concentrations 


\begin{tabular}{cccccc} 
Anion/ppm & $\mathrm{A}$ & $\mathrm{B}$ & $\mathrm{C}$ & $\mathrm{D}$ & $\mathrm{E}$ \\
\cline { 2 - 6 } $\mathrm{Cl}^{-}$ & $29285 \pm 5118$ & $29534 \pm 5973$ & $29147 \pm 9123$ & $30151 \pm 6276$ & $29437 \pm 5959$ \\
$\mathrm{NO}_{3}^{-}$ & $7.8 \pm 4.1$ & $6.8 \pm 7.1$ & $17.1 \pm 6.1$ & $12.7 \pm 5.1$ & $10.8 \pm 8.1$ \\
$\mathrm{PO}_{4}^{-3}$ & $66.1 \pm 24.9$ & $54.3 \pm 13.5$ & $74.7 \pm 21.4$ & $83.7 \pm 28.4$ & $89 \pm 35.9$ \\
$\mathrm{SO}_{4}^{-2}$ & $2045.2 \pm 485$ & $2200 \pm 543$ & $2391.1 \pm 591.5$ & $2726.3 \pm 628.5$ & $2111.4 \pm 745.9$
\end{tabular}

213 Finally, micronutrients and heavy metals were analysed. Micronutrients in nutritional terms are 214 negligible, except for boron, which reached averages above 12 ppm or 1.1 mmol (Table 3). 215 These values are approximately 40 times higher than those needed to mix a balanced nutritive 216 solution [35]. Heavy metals (Table 3) are presented in ppb. Before dilution, except for $\mathrm{Hg}$ from 217 some desalination facilities, they showed quantities lower than the maximum permitted in 218 vegetables by the World Health Organisation [58]. However, the working dilutions are usually 219 higher than 1/40, and previous work demonstrates how heavy metals were not accumulated in 220 tomato fruits [30]. In addition, no Escherichia coli, Enterococcus or Clostridium perfringens 221 were found (data not shown) in the reject brine analysis. This is consistent with previous findings 222 because $E$ coli, for instance, is not able to survive after $72 \mathrm{~h}$ in a $20 \% \mathrm{NaCl}$ solution [59].

Table 3. Year-long average macronutrient and heavy metal concentrations

\section{Desalination facility}

A $\quad$ B $\quad$ C $\quad$ D $\quad$ E

\begin{tabular}{|c|c|c|c|c|c|c|}
\hline \multirow[b]{2}{*}{$\begin{array}{l}\text { Micronutrients } \\
\text { ppm }\end{array}$} & $A$ & B & C & D & E & \\
\hline & & & & & & \\
\hline $\mathrm{Cu}$ & $1.3 \pm 0.3$ & $1.3 \pm 0.3$ & $1.2 \pm 0.1$ & $\begin{array}{c}1.2 \pm \\
0.1\end{array}$ & $2.4 \pm 1$ & \\
\hline $\mathrm{Mn}$ & $4.8 \pm 2.3$ & $2.6 \pm 0.1$ & $3 \pm 0.7$ & $\begin{array}{c}2.4 \pm \\
0.1\end{array}$ & $2.7 \pm 0.3$ & \\
\hline $\mathrm{Fe}$ & $6.8 \pm 2.3$ & $2.5 \pm 2$ & $2 \pm 1.6$ & $1.5 \pm 2$ & $1.2 \pm 2$ & \\
\hline $\mathrm{B}$ & $19.7 \pm 3$ & $16.1 \pm 4$ & $8.7 \pm 2$ & $7.8 \pm 2$ & $8.7 \pm 2$ & \\
\hline $\begin{array}{l}\text { Heavy metals } \\
\text { ppb }\end{array}$ & & & & & & $\begin{array}{c}\text { Permitted levels in } \\
\text { foodll }\end{array}$ \\
\hline As & $0.5 \pm 0.2$ & $0.6 \pm 0.2$ & $1 \pm 0.4$ & 0 & $2.2 \pm 0.8$ & 100 \\
\hline $\mathrm{Hg}$ & $\begin{array}{c}140.6 \pm \\
50\end{array}$ & $\begin{array}{c}115.7 \pm \\
40\end{array}$ & $\begin{array}{c}54.4 \pm \\
10\end{array}$ & $55.6 \pm 9$ & $\begin{array}{c}39.5 \pm \\
20\end{array}$ & 100 \\
\hline $\mathrm{Cd}$ & $2 \pm 0.2$ & $1.8 \pm 0.1$ & $1.9 \pm 0.3$ & $\begin{array}{l}2.3 \pm \\
0.4\end{array}$ & $2.2 \pm 0.5$ & 20 \\
\hline $\mathrm{Ni}$ & $1.4 \pm 0.4$ & $3.3 \pm 0.4$ & $1.9 \pm 1$ & $4.9 \pm 1$ & $3 \pm 1$ & 10 \\
\hline
\end{tabular}


226 Seawater reject brines in general could be a predictable and reliable source of macronutrients if 227 the mineral contents were similar and independent of facility location. Unfortunately, this is not 228 the case between Spanish Mediterranean and Atlantic (Canary Islands) facilities (Table 1). 229 Analysis of reject brines from the former showed a significantly higher content of three 230 macronutrient ions. Specifically, $\mathrm{Ca}^{2+}$ and $\mathrm{K}^{+}$were around 300 ppm higher, the differences being 231 even higher for $\mathrm{Mg}^{2+}$ (by 500 ppm, Figure 4).

233

234

235

236

237

238

239

240

241

242

243

244

245

246

247

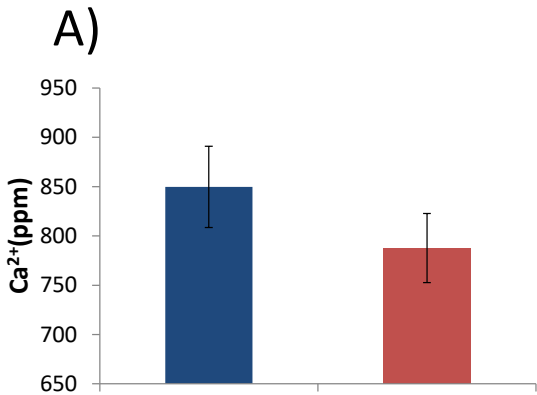

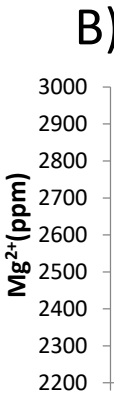

B)

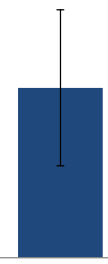

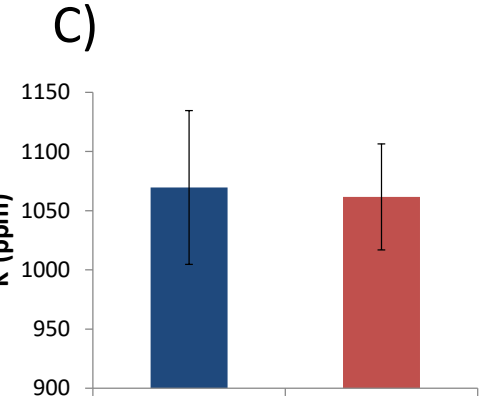

Figure 4. Macronutrient analyses of reject seawater brine from two desalination facilities in Spanish Mediterranean areas. A) Calcium, B) Magnesium, and C) Potassium concentrations from Alicante and Murcia desalination facilities, shown in blue and red respectively. Bars marked with the same letter show no statistical differences $(\mathrm{p}<0.05)$.

That trend is found worldwide on analysing the data from various desalination facilities (Table 4). Published data showed a similar ion concentration in brine from facilities on Atlantic or Pacific coasts [60] and higher $\mathrm{Ca}^{2+}, \mathrm{K}^{+} ; \mathrm{Mg}^{2+}$ ion levels in brine from those in the semi-closed Mediterranean Sea or the Persian Gulf [61,62]. This dependency on location is striking, especially on comparing seawater reject brines from desalination facilities only $500 \mathrm{~km}$ apart. The reject brine from Abu Dhabi in the Gulf had higher $\mathrm{Ca}^{2+}, \mathrm{K}^{+}$and $\mathrm{Mg}^{2+}$ levels than that from Muscat on the Indian Ocean, again showing the important influence of water bodies on brine composition. In contrast, those from facilities that use groundwaters as feed source were highly inconsistent in their contents. Calcium levels varied from 500 ppm to $2800 \mathrm{ppm}, \mathrm{K}^{+}$from 32 ppm to 220 ppm and $\mathrm{Mg}^{2+}$ from 189 ppm to 7200 ppm.

Table 4: Reject brine macronutrient concentrations around the world.

\section{Desalination facility}

\begin{tabular}{ccccccc} 
Plant & Water source & Facility type & $\mathrm{Ca}^{2+} \mathrm{ppm}$ & $\mathrm{K}^{+} \mathrm{ppm}$ & $\mathrm{Mg}^{2+} \mathrm{ppm}$ & Ref. \\
\cline { 2 - 7 } Tenerife $^{+}$ & Seawater & $\mathrm{RO}$ & $555.62 \pm 20.81$ & $864.7 \pm 25.7$ & $2090 \pm 84.1$ & $\mathrm{M}$ \\
Alicante & Seawater & $\mathrm{RO}$ & $849.7 \pm 41.2$ & $1069.6 \pm 64.9$ & $2659.7 \pm 211$ & $\mathrm{M}$
\end{tabular}




\begin{tabular}{|c|c|c|c|c|c|c|}
\hline Murcia & Seawater & RO & $787.7 \pm 35$ & $1061.7 \pm 44.7$ & $2575.3 \pm 91.7$ & $M$ \\
\hline Australia & Seawater & RO & 662 & 1220 & 2260 & {$[60]$} \\
\hline Abu Dhabi & Seawater & RO & 760 & 950 & 2660 & \\
\hline Muscat & Seawater & RO & 625 & 668 & 1830 & \\
\hline Brazil & Groundwater & RO & 1404 & NS & 1056 & [28] \\
\hline Israel & Groundwater & RO & 959.4 & 70.4 & 378.5 & \\
\hline Bahja* & Groundwater & RO & $1850 \pm 98$ & $220 \pm 7.1$ & $445 \pm 21$ & \\
\hline Rima* & Groundwater & $\mathrm{RO}$ & 2850 & 152 & 670 & \\
\hline Nimr* & Groundwater & RO & $1585 \pm 106.6$ & $141.5 \pm 2.2$ & $326 \pm 25$ & \\
\hline Marmul $^{*}$ & Groundwater & RO & $518.5 \pm 4.9$ & 32 & $189 \pm 5.6$ & \\
\hline Abu Dhabi & Groundwater & RO & 202 & 84.5 & 510 & 2] \\
\hline
\end{tabular}

$249+$ Mean yearly average from the five studied brines; *means of two brines analysed; RO: means

250 from reverse osmosis plant. NS: means data not shown. M: means measured in this study.

252 The data collected in Table 4 opens an interesting discussion about the need to properly regulate

253 brine disposal into an almost closed water body like the Mediterranean. Its evaporation rate has

254 increased by 20-30\% over the period 1950-2010, which involves an 8 to $12 \%$ rise in salinity

255 [64]. Researchers point out that the sea level is rising by between 0.03 and $0.3 \mathrm{~mm} /$ year in winter

256 and about a third of this year-round [65]. Therefore, desalination facilities can continue using

257 that sea as water resource, provided an integrated waste policy ensures a sustainable balance

258 between environment and human activities [66]. Indeed, several long-term studies document

259 negative impacts on benthic fauna, flora and algae near the brine discharge zone [17].

260 Environmental implications, followed by several associated problems that include closure of

261 recreational facilities, noise and air pollution and aesthetic degradation are among the most usual

262 reasons for this, often termed "Not In My Backyard (NIMBY)" [67]. One third of the

263 Mediterranean population lives near the coastal regions, which involves an increase in activities

264 such as tourism and agriculture, and consequently higher water consumption [68]. Nowadays,

265 desalination is a costly water supply option for the Mediterranean regions [69], now requiring a

266 technically and economically viable alternative that contributes to the sustainability of

267 agriculture and water resources [70]. However, well-considered actions to reduce environmental

268 impact and related rejection by local residents are the key to continuing water supply systems

269 based on desalination in this and other low-rainfall regions. 


\subsection{Reject brine as a source of mineral salts for crops in hydroponic systems}

274 The seawater reject brine was previously treated to produce the well-known Hoagland and Arnon 275 solution [35] and later used as nutritive solution for a commercial fruit crop. This approach could 276 be applied to a range of crops if the reject brine is adjusted with specific amendments, according 277 to their respective nutritional requirements. Tables 5 and 6 show an example of the brine 278 dilutions used to achieve the amendments needed for two profitable commercial crops (tomato 279 and carnation), using reject brine values from three desalination facilities on Tenerife, and others 280 in the Mediterranean, Australia and Abu Dhabi.

281 The specific nutritive solution for the tomato crop has a calculated conductivity near $3.2 \mathrm{dS} / \mathrm{m}$, 282 which is around 50\% lower than in a previous study [30]. These conductivity differences 283 between the optimised solution (Table 5) and those previously published depend on the higher 284 mineral content of the Hoagland solution [71], which is reflected in much higher conductivity. 285 Using a nutritive solution with high or low conductivity in this crop did not induce a notable 286 variation in productivity [72]. However, high conductivity in the nutritive solution improves fruit 287 firmness, colour and flavour [73]. In this regard, using brine to prepare the nutritive solution may 288 reduce production costs by 14-20\%, depending on its origin. Applying a modernised controlled 289 hydroponic system like NFT where the solution circulates [72], crop yields can reach an average 290 of $2.74 \mathrm{~kg} /$ plant [74]. These can reach higher productivities of $161.8 \pm 6.6$ ton per hectare, 291 compared to $10.07 \pm 0.4$ in soil [75]. Furthermore, Spain operates more than half of all Europe's 292 desalination capacity [76,77], which offers an excellent opportunity to install this procedure with 293 the mentioned cost savings and better organoleptic features for Spain's horticutural produce. 294 Implementation of reject brine use in hydroponic systems could become an exciting project to 295 rescue this crop sector in territories like Spain, which has lost competitiveness compared to other 296 producers in Europe and nearby [78].

297 Table 5. Optimised hydroponic solution for tomato cultivation with or without brine.

\begin{tabular}{|c|c|c|c|c|c|c|c|}
\hline & \multirow[b]{2}{*}{ Salts } & & \multicolumn{5}{|c|}{$\begin{array}{c}\text { Quantities of salts needed for } 25 \mathrm{~L} \text { of stock solution with or } \\
\text { without reject brine }\end{array}$} \\
\hline & & & No brine & $1 / 55$ TF $^{1}$ & 1/70 MED ${ }^{1}$ & 1/70 AUS 1 & $1 / 70 A D^{1}$ \\
\hline \multirow[t]{3}{*}{ Stock 1} & $\mathrm{Ca}\left(\mathrm{NO}_{3}\right)_{2}$ & $(\mathrm{Kg})$ & 2.16 & 1.01 & 1.00 & 0.6 & 0.60 \\
\hline & $\mathrm{NH}_{4} \mathrm{NO}_{3}$ & (g) & 40 & 30 & 30 & 20 & 20 \\
\hline & $\mathrm{KNO}_{3}$ & (g) & 400 & - & - & - & - \\
\hline
\end{tabular}



Fe-EDDHA
(g)
34.9
12.78
17.45
10.4
9.61

Stock $2 \quad \mathrm{MgSO}_{4}$

$\mathrm{KH}_{2} \mathrm{PO}_{4}$

(g)

950

$\mathrm{KNO}_{3}$

(g)

340

$\mathrm{K}_{2} \mathrm{SO}_{4}$

(g)

870

170

170

100

100

$\mathrm{H}_{3} \mathrm{BO}_{3}$

(g)

450

700

710

420

420

$\mathrm{CuSO}_{4}$

(g)

3.08

120

120

80

80

$\mathrm{ZnSO}_{4}$

(g)

0.62

0.11

1.03

0.92

0.92

$\mathrm{MnSO}_{4}$

$\left(\mathrm{NH}_{4}\right)_{6} \mathrm{Mo}_{7} \mathrm{O}_{24}$

(g)

(mg)

3.6

1.58

0.31

0.19

0.19

1.58

1.80

1.08

1.08

4.23

440

1.90

2.11

1.24

1.24

220

130

Stock dilutions used $\quad 1: 100$

Expected conductivity (dS/m)

2.09

$1: 50$

$1: 50$

130

$1: 30$

1.15

3.19

3.18

$1: 30$

3.15

Nutritive solution cost $\left(€ \mathrm{~m}^{3}\right)$

0.94

1.01

3.15

0.96

1. Amounts of salts were calculated using average mineral content of reject brines from desalination facilities at the specific locations. TF, Tenerife; MED, Mediterranean; AUS, Australia [60]; AD, Abu-Dhabi [62].

298 A similar approach could be used in the floriculture sector. Carnations are an important crop 299 occupying more than 6000 ha [79] worldwide, and their hydroponic cultivation is not only viable

300 [80] but an excellent alternative to conventional systems [81]. Previous studies confirmed 301 excellent carnation production and quality using solutions with conductivities between 3-4.8

$302 \mathrm{dS} / \mathrm{m}$ under continuous irrigation, without changes in flower weight or colour attributes $[82,83]$.

303 The recommended solution (Table 6) using reject brine as a mineral source exhibits conductivity

304 levels below $3 \mathrm{dS} / \mathrm{m}$. These reduces costs by between 10-17\%, depending on the precise brine

305 composition. This opens up the possibility of utilising such brines as a mineral source in

306 carnation production, in addition to more economical hydroponic systems in other horticultural

307 and floricultural crops (Supplementary Tables 1 to 7).

Table 6. Optimised hydroponic solution for carnation cultivation with or without brine.

\begin{tabular}{|c|c|c|c|c|c|c|c|}
\hline & \multirow[b]{2}{*}{ Salts } & & \multicolumn{5}{|c|}{$\begin{array}{l}\text { Quantities of salts needed for } 25 \mathrm{~L} \text { of stock solution with or } \\
\text { without reject brine }\end{array}$} \\
\hline & & & No brine & $1 / 80 \mathrm{TF}^{1}$ & 1/70 MED 1 & $1 / 80$ AUS $^{1}$ & $1 / 80 A D^{1}$ \\
\hline \multirow[t]{4}{*}{ Stock 1} & $\mathrm{Ca}\left(\mathrm{NO}_{3}\right)_{2}$ & $(\mathrm{Kg})$ & 1.89 & 0.9 & 0.86 & 0.53 & 0.53 \\
\hline & $\mathrm{NH}_{4} \mathrm{NO}_{3}$ & (g) & 60 & 30 & 40 & 20 & 20 \\
\hline & $\mathrm{KNO}_{3}$ & (g) & 240 & - & - & - & - \\
\hline & Fe-EDDHA & (g) & 58.25 & 26.6 & 20.13 & 17.48 & 17.48 \\
\hline \multirow[t]{4}{*}{ Stock 2} & $\mathrm{MgSO}_{4}$ & (g) & 760 & 40 & - & 10 & - \\
\hline & $\mathrm{KH}_{2} \mathrm{PO}_{4}$ & (g) & 440 & 220 & 220 & 130 & 130 \\
\hline & $\mathrm{KNO}_{3}$ & (g) & 1030 & 680 & 710 & 410 & 420 \\
\hline & $\mathrm{H}_{3} \mathrm{BO}_{3}$ & (g) & 4.63 & 1.33 & 1.8 & 1.39 & $1 . .39$ \\
\hline
\end{tabular}




\begin{tabular}{ccccccc}
$\mathrm{CuSO}_{4}$ & $(\mathrm{~g})$ & 0.62 & - & 0.31 & 0.19 & 0.19 \\
$\mathrm{ZnSO}_{4}$ & $(\mathrm{~g})$ & 3.6 & 1.65 & 1.80 & 1.08 & 1.08 \\
$\mathrm{MnSO}_{4}$ & $(\mathrm{~g})$ & 4.23 & 1.96 & 2.11 & 1.27 & 1.25 \\
$\left(\mathrm{NH}_{4}\right)_{6} \mathrm{Mo}_{7} \mathrm{O}_{24}$ & $(\mathrm{mg})$ & 440 & - & 220 & 130 & 130 \\
& & & & & \\
Stock dilutions used & $1: 100$ & $1: 50$ & $1: 50$ & $1: 30$ & $1: 30$ \\
Expected conductivity (dS/m) & 1.78 & 2.58 & 3.02 & 2.97 & 2.8 \\
Nutritive solution cost (€ $\left.\mathbf{m}^{3}\right)$ & 1.18 & 1.05 & 1.09 & 1.1 & 1.09 \\
\hline
\end{tabular}

1. Amounts of salts were calculated using average mineral content of reject brines from desalination facilities at the specific locations. TF, Tenerife; MED, Mediterranean; AUS, Australia [60]; AD, Abu-Dhabi [62].

\subsection{Economic study of using reject brine in a soilless tomato plantation}

310 The present research line has already highlighted the benefits of reject brine use in small-scale

311 laboratory hydroponic systems [30]. However, no studies or estimates for reject brine use in a

312 typical greenhouse hydroponic facility have been examined. In the Canary Islands, a 2 ha

313 hydroponic tomato crop greenhouse could have two harvests per year and a building cost

314 between 25 to $84 € / \mathrm{m}^{2}$ [84]. This needs an opening investment of $€ 1,080,000$. Furthermore,

315 considering the production costs and incomes per year and the NFT hydroponic system running

316 costs, the farmer would need eleven years to recover the opening investment (Table 7).

\section{Table 7. Reject brine implementation study}

\begin{tabular}{|c|c|c|c|c|}
\hline \multirow{3}{*}{ Concept } & \multicolumn{4}{|c|}{ Two-hectare tomato production costs } \\
\hline & \multicolumn{2}{|r|}{$\begin{array}{c}\text { Without } \\
\text { brine }\end{array}$} & \multicolumn{2}{|r|}{$\begin{array}{l}\text { With } \\
\text { brine }\end{array}$} \\
\hline & $€ / m^{2}$ & Two season cost & $€ / m^{2}$ & Two season cost \\
\hline Water used & 0.15 & 6,000 & 0.15 & 6,000 \\
\hline Fertiliser & 0.46 & 18,400 & 0.36 & 14,400 \\
\hline Other cost (Plants, Pesticides, Labour, Energy, etc.) & 4.41 & 176,400 & 4.41 & 176,400 \\
\hline Total cost & 5.02 & 200,800 & 4.77 & 190,800 \\
\hline Income $€ / \mathrm{m}^{2}$ & 7.48 & 299,200 & 7.48 & 299,200 \\
\hline Net income & 2.46 & 98,400 & 2.71 & 102,400 \\
\hline Years to recover initial investment & & 11 & & 10.5 \\
\hline
\end{tabular}

318 Previous studies demonstrate how reject brine could diminish fertilisation costs by $21 \%$ using 319 1/55 dilution without any productivity losses [72]. That means an extra income of $4000 €$ per 320 year, being $4 \%$ more profit, reducing the pay-off period by six months. For comparison, it is 321 interesting that tomato production in soil produces a yearly net income of $13,797 €$ per hectare in 322 the Spanish Mediterranean [85], much less in countries like Turkey: 1,592 to 2,218 € [86]. 323 However, recent studies point out that in some regions of Spain most of the producers worked at 
324 a loss [87]. This highlights the importance of moving towards improved systems such as

325 hydroponics, and brine reutilisation can help with this transition.

327 Beyond the direct savings in fertilisation, reject brines bring opportunities to increase profits. 328 One option is to use brine as a new source of freshwater. A short-cut approach to minimise energy costs is the capture and direct utilisation of solar energy to evaporate the brine and obtain

330 water. In the bibliography there are descriptions of several alternative techniques (for an 331 extensive review see [88]). One problem affecting this kind of evaporator is final production 332 price of water, to save enough on its maintenance cost and to recuperate the initial investment in 333 the evaporator. This may be on average from $0.023 € / L$ [89], reaching unaffordable water prices 334 for the producers. Another problem is that most of these systems are optimised for seawater, not 335 for brine, in which the high evaporation rate needed to maintain water output cannot be 336 maintained [90] due to high salinity. In this regard, new materials used as surface covers can 337 keep or increase evaporation rates [90-93], which presents an interesting field for optimisation 338 to use brine as water source for agricultural fields.

339 In this context, a promising commercial evaporator is the SunAqua-18 [94] system designed by 340 aqua-abib®. It consists of a pyramid-shaped structure with an octagonal base, measuring $18 \mathrm{~m}$ in 341 height, covering an area of 2,500 $\mathrm{m}^{2}$. This technology harvests sunlight with $70 \%$ efficiency, 342 heating the air between two plastic layers and the vapour naturally rises to the top of the pyramid 343 surpassing $100{ }^{\circ} \mathrm{C}$ [95]. According to the development team, the equipment can produce 25,000 $344 \mathrm{~m}^{3}$ of freshwater using desalination reject brine as supply source [94], with a low energy 345 consumption. This volume is well above the $6,000 \mathrm{~m}^{3}$ needed by the Hydroponic Nutrient Film 346 Technique (NFT) system in continuous production with two harvests per year. This could 347 provide extra revenue selling the surplus freshwater. Indeed, the average price for desalinated 348 water in Spain is $0.6 € / \mathrm{m}^{3}$, giving an extra $11,400 €$. However, the final viability must consider 349 the time to pay off the investment in the evaporator, and its running costs (precise figures are 350 currently unavailable).

351 Another method to obtain revenues from rejected brine worth exploring is to couple evaporation 352 with precipitation protocols. An interesting study [63] proposes treatment options to apply 353 reverse osmosis to reject brine. The simplest process produces substantial amounts of sodium 
354 chloride and gypsum, with a market price of 8.2 and $7.1 €$ per tonne respectively [96], and also 355 other more valuable compounds such as magnesium hydroxide, used to obtain the pure 356 magnesium oxide widely used for pharmaceutical and semiconductor purposes [97]. An 357 interesting review [98] is focused on the processes necessary to obtain these and other elements 358 from reject brine. Altogether, excellent avenues for further research into these techniques are 359 foreseeable, applying circularity paradigms to increase secondary income.

\section{Conclusions}

362 Desalination is probably one of the fundamental technologies capable of solving the world water 363 scarcity problem. However, managing the seawater reject brine produced during the process is a 364 significant concern preventing this technology from expanding worldwide.

365 This one-year study shows how this brine could be an excellent source of valuable 366 macronutrients. Specific minerals were found in constant reliable high concentrations $\left(\mathrm{Ca}^{2+}, \mathrm{K}^{+}\right.$ 367 and $\mathrm{Mg}^{2+} \mathrm{SO}^{4-}$ and $\mathrm{B}^{-}$) during the analyses, independently of the facility location.

368 Brine implementation in an hydroponic cultivation is rentable, due the reduction in crop 369 production costs due to using less fertiliser, producing an extra revenue of $4000 €$ per year. This 370 shortens the payback time by six months. Data available from desalination facilities worldwide 371 confirm how this system can be used to provide similar reductions in running costs in a plethora 372 of commercial horticultural and floricultural crops.

373 Utilisation of freshwater produced from brine with a proper evaporation system has the potential 374 to generate extra revenue of $€ 17,400$ ( $€ 6,000$ from water input cost savings $+€ 11,400$ by selling 375 the surplus fresh water generated). This income could also be increased by selling or using the 376 salts obtained after brine evaporation. In any case, appropriate research has still to be done to 377 more reliably estimate the total potential profit, and amortisation time required to recuperate 378 investment in the new infrastructure.

379 Finally, this system based on a raw material such as brine allows the general public to visualise 380 and understand the opportunities for applying desalination technologies beyond fresh water 381 generation, thus promoting wider acceptance of this technology. With an optimised design, 382 implementation of such a set-up not only increases profitable food production, it also shows a 383 way to reach beyond the current semi-sustainable desalination facilities. 


\section{Author contribution statement}

David Jiménez-Arias: Conceptualisation, Research and Data curation; Sarai Morales-Sierra: Research; Francisco J. García-Machado: Research; Ana L. García-García: Research; Juan C.

388 Luis: Writing - Original Draft; Andrés A. Borges: Funding acquisition, Supervision.

\section{Declaration of competing interest}

390 The authors declare that the research was conducted in the absence of any commercial or

391 financial relationships that could be construed as a potential conflict of interest.

\section{Acknowledgements}

393 F.J.G.-M. and A.G.G., PhD students at the University of La Laguna, were supported by research 394 fellowship contracts from the Gobierno de Canarias. The manuscript was revised by G. Jones, funded by Cabildo de Tenerife under the TFinnova Programme, supported by MEDI and FDCAN. We also thank TAGUA S.L. and the Mancomunidad de los Canales del Taibilla, (especially Luis González and Ruben Navarro Barrio respectively) for providing reject brine from their seawater desalination facilities.

\section{Bibliography}

[1] F. Shoushtarian, M. Negahban-Azar, Worldwide Regulations and Guidelines for Agricultural Water Reuse: A Critical Review, Water. 12 (2020) 971. https://doi.org/10.3390/w12040971.

[2] J.F. Velasco-Muñoz, J.A. Aznar-Sánchez, L.J. Belmonte-Ureña, I.M. Román-Sánchez, Sustainable Water Use in Agriculture: A Review of Worldwide Research, Sustainability. 10 (2018) 1084. https://doi.org/10.3390/su10041084.

[3] A. Mishra, E. Bruno, D. Zilberman, Compound natural and human disasters: Managing drought and COVID-19 to sustain global agriculture and food sectors, Science of The Total Environment. 754 (2021) 142210. https://doi.org/10.1016/j.scitotenv.2020.142210.

[4] S. Lavrnić, M. Zapater-Pereyra, M.L. Mancini, Water Scarcity and Wastewater Reuse Standards in Southern Europe: Focus on Agriculture, Water Air Soil Pollut. 228 (2017) 251. https://doi.org/10.1007/s11270-017-3425-2.

[5] N.C. Darre, G.S. Toor, Desalination of Water: a Review, Curr Pollution Rep. 4 (2018) 104111. https://doi.org/10.1007/s40726-018-0085-9.

[6] N. Ghaffour, T.M. Missimer, G.L. Amy, Technical review and evaluation of the economics of water desalination: Current and future challenges for better water supply sustainability, Desalination. 309 (2013) 197-207. https://doi.org/10.1016/j.desal.2012.10.015.

[7] J. Eke, A. Yusuf, A. Giwa, A. Sodiq, The global status of desalination: An assessment of current desalination technologies, plants and capacity, Desalination. 495 (2020) 114633. https://doi.org/10.1016/j.desal.2020.114633.

[8] E. Jones, M. Qadir, M.T.H. van Vliet, V. Smakhtin, S. Kang, The state of desalination and brine production: A global outlook, Science of The Total Environment. 657 (2019) 13431356. https://doi.org/10.1016/j.scitotenv.2018.12.076.

[9] J.J. Feria-Díaz, F. Correa-Mahecha, M.C. López-Méndez, J.P. Rodríguez-Miranda, J. Barrera-Rojas, Recent Desalination Technologies by Hybridization and Integration with Reverse Osmosis: A Review, Water. 13 (2021) 1369. https://doi.org/10.3390/w13101369. 
[10] U. Caldera, C. Breyer, Strengthening the global water supply through a decarbonised global desalination sector and improved irrigation systems, Energy. 200 (2020) 117507. https://doi.org/10.1016/j.energy.2020.117507.

[11] H. Shemer, R. Semiat, Sustainable RO desalination - Energy demand and environmental impact, Desalination. 424 (2017) 10-16. https://doi.org/10.1016/j.desal.2017.09.021.

[12] D.A. Roberts, E.L. Johnston, N.A. Knott, Impacts of desalination plant discharges on the marine environment: A critical review of published studies, Water Research. 44 (2010) 5117-5128. https://doi.org/10.1016/j.watres.2010.04.036.

[13] S. Miller, H. Shemer, R. Semiat, Energy and environmental issues in desalination, Desalination. 366 (2015) 2-8. https://doi.org/10.1016/j.desal.2014.11.034.

[14] A. Hurlimann, S. Dolnicar, Public acceptance and perceptions of alternative water sources: a comparative study in nine locations, International Journal of Water Resources Development. 32 (2016) 650-673. https://doi.org/10.1080/07900627.2016.1143350.

[15] B. Haddad, N. Heck, A. Paytan, D. Potts, Chapter 14 - Social Issues and Public Acceptance of Seawater Desalination Plants, in: V.G. Gude (Ed.), Sustainable Desalination Handbook, Butterworth-Heinemann, 2018: pp. 505-525. https://doi.org/10.1016/B978-0-12809240-8.00014-9.

[16] R.S. Carson PhD ESEP, "Not in My Backyard" is Not Sustainable, INCOSE International Symposium. 27 (2017) 1749-1766. https://doi.org/10.1002/j.23345837.2017.00460.x.

[17] C. Kenigsberg, S. Abramovich, O. Hyams-Kaphzan, The effect of long-term brine discharge from desalination plants on benthic foraminifera, PLOS ONE. 15 (2020) e0227589. https://doi.org/10.1371/journal.pone.0227589.

[18] M.L. Cambridge, A. Zavala-Perez, G.R. Cawthray, J. Statton, J. Mondon, G.A. Kendrick, Effects of desalination brine and seawater with the same elevated salinity on growth, physiology and seedling development of the seagrass Posidonia australis, Marine Pollution Bulletin. 140 (2019) 462-471. https://doi.org/10.1016/j.marpolbul.2019.02.001.

[19] A. Garrote-Moreno, Y. Fernández-Torquemada, J.L. Sánchez-Lizaso, Salinity fluctuation of the brine discharge affects growth and survival of the seagrass Cymodocea nodosa, Marine Pollution Bulletin. 81 (2014) 61-68. https://doi.org/10.1016/j.marpolbul.2014.02.019.

[20] J.A. de-la-Ossa-Carretero, Y. Del-Pilar-Ruso, A. Loya-Fernández, L.M. Ferrero-Vicente, C. Marco-Méndez, E. Martinez-Garcia, J.L. Sánchez-Lizaso, Response of amphipod assemblages to desalination brine discharge: Impact and recovery, Estuarine, Coastal and Shelf Science. 172 (2016) 13-23. https://doi.org/10.1016/j.ecss.2016.01.035.

[21] A. Panagopoulos, K.-J. Haralambous, M. Loizidou, Desalination brine disposal methods and treatment technologies - A review, Science of The Total Environment. 693 (2019) 133545. https://doi.org/10.1016/j.scitotenv.2019.07.351.

[22] I. Ihsanullah, M.A. Atieh, M. Sajid, M.K. Nazal, Desalination and environment: A critical analysis of impacts, mitigation strategies, and greener desalination technologies, Science of The Total Environment. 780 (2021) 146585. https://doi.org/10.1016/j.scitotenv.2021.146585.

[23] A. Pistocchi, T. Bleninger, C. Breyer, U. Caldera, C. Dorati, D. Ganora, M.M. Millán, C. Paton, D. Poullis, F.S. Herrero, M. Sapiano, R. Semiat, C. Sommariva, S. Yuece, G. Zaragoza, Can seawater desalination be a win-win fix to our water cycle?, Water Research. 182 (2020) 115906. https://doi.org/10.1016/j.watres.2020.115906. 
[24] G.P. Thiel, A. Kumar, A. Gómez-González, J.H. Lienhard, Utilization of Desalination Brine for Sodium Hydroxide Production: Technologies, Engineering Principles, Recovery Limits, and Future Directions, ACS Sustainable Chem. Eng. 5 (2017) 11147-11162. https://doi.org/10.1021/acssuschemeng.7b02276.

[25] T. Akinaga, S.C. Generalis, C. Paton, O.N. Igobo, P.A. Davies, Brine utilisation for cooling and salt production in wind-driven seawater greenhouses: Design and modelling, Desalination. 426 (2018) 135-154. https://doi.org/10.1016/j.desal.2017.10.025.

[26] S. Panta, P. Lane, R. Doyle, M. Hardie, G. Haros, S. Shabala, 19 - Halophytes as a Possible Alternative to Desalination Plants: Prospects of Recycling Saline Wastewater During Coal Seam Gas Operations, in: M.A. Khan, M. Ozturk, B. Gul, M.Z. Ahmed (Eds.), Halophytes for Food Security in Dry Lands, Academic Press, San Diego, 2016: pp. 317-329. https://doi.org/10.1016/B978-0-12-801854-5.00019-4.

[27] H. Al-Faifi, A.M. Al-Omran, M. Nadeem, A. El-Eter, H.A. Khater, S.E. El-Maghraby, Soil deterioration as influenced by land disposal of reject brine from Salbukh water desalination plant at Riyadh, Saudi Arabia, Desalination. 250 (2010) 479-484. https://doi.org/10.1016/j.desal.2009.06.077.

[28] A.S. Sánchez, I.B.R. Nogueira, R.A. Kalid, Uses of the reject brine from inland desalination for fish farming, Spirulina cultivation, and irrigation of forage shrub and crops, Desalination. 364 (2015) 96-107. https://doi.org/10.1016/j.desal.2015.01.034.

[29] O. Yildirim, D. Tunay, B. Ozkaya, Reuse of sea water reverse osmosis brine to produce Dunaliella salina based $\beta$-carotene as a valuable bioproduct: A circular bioeconomy perspective, Journal of Environmental Management. 302 (2022) 114024. https://doi.org/10.1016/j.jenvman.2021.114024.

[30] D. Jiménez-Arias, S. Morales-Sierra, F.J. García-Machado, A.L. García-García, J.C. Luis, F. Valdés, L.M. Sandalio, M. Hernández-Suárez, A.A. Borges, Rejected brine recycling in hydroponic and thermo-solar evaporation systems for leisure and tourist facilities. Changing waste into raw material, Desalination. 496 (2020) 114443. https://doi.org/10.1016/j.desal.2020.114443.

[31] T. Gomiero, Soil Degradation, Land Scarcity and Food Security: Reviewing a Complex Challenge, Sustainability. 8 (2016) 281. https://doi.org/10.3390/su8030281.

[32] P.M. Kopittke, N.W. Menzies, P. Wang, B.A. McKenna, E. Lombi, Soil and the intensification of agriculture for global food security, Environment International. 132 (2019) 105078. https://doi.org/10.1016/j.envint.2019.105078.

[33] Y. Ibrahim, R.A. Ismail, A. Ogungbenro, T. Pankratz, F. Banat, H.A. Arafat, The sociopolitical factors impacting the adoption and proliferation of desalination: A critical review, Desalination. 498 (2021) 114798. https://doi.org/10.1016/j.desal.2020.114798.

[34] K. Hartley, C. Tortajada, A.K. Biswas, A formal model concerning policy strategies to build public acceptance of potable water reuse, Journal of Environmental Management. 250 (2019) 109505. https://doi.org/10.1016/j.jenvman.2019.109505.

[35] D.R. Hoagland, D.I. Arnon, The water-culture method for growing plants without soil., Circular. California Agricultural Experiment Station. 347 (1950). https://www.cabdirect.org/cabdirect/abstract/19500302257 (accessed May 31, 2021).

[36] R. Kathpalia, S.C. Bhatla, Plant Mineral Nutrition, in: S.C. Bhatla, M. A. Lal (Eds.), Plant Physiology, Development and Metabolism, Springer, Singapore, 2018: pp. 37-81. https://doi.org/10.1007/978-981-13-2023-1_2. 
[37] K. Thor, Calcium-Nutrient and Messenger, Front. Plant Sci. 10 (2019). https://doi.org/10.3389/fpls.2019.00440.

[38] M.S. Aghdam, M.B. Hassanpouraghdam, G. Paliyath, B. Farmani, The language of calcium in postharvest life of fruits, vegetables and flowers, Scientia Horticulturae. 144 (2012) 102-115. https://doi.org/10.1016/j.scienta.2012.07.007.

[39] D. Hagassou, E. Francia, D. Ronga, M. Buti, Blossom end-rot in tomato (Solanum lycopersicum L.): A multi-disciplinary overview of inducing factors and control strategies, Scientia Horticulturae. 249 (2019) 49-58. https://doi.org/10.1016/j. scienta.2019.01.042.

[40] M. Macias-González, M.J. Truco, L.D. Bertier, S. Jenni, I. Simko, R.J. Hayes, R.W. Michelmore, Genetic architecture of tipburn resistance in lettuce, Theor Appl Genet. 132 (2019) 2209-2222. https://doi.org/10.1007/s00122-019-03349-6.

[41] K. Murai, N.J. Chen, R.E. Paull, Pineapple crown and slip removal on fruit quality and translucency, Scientia Horticulturae. 283 (2021) 110087. https://doi.org/10.1016/j.scienta.2021.110087.

[42] T. Yang, H.-J. Kim, Nutrient management regime affects water quality, crop growth, and nitrogen use efficiency of aquaponic systems, Scientia Horticulturae. 256 (2019) 108619. https://doi.org/10.1016/j.scienta.2019.108619.

[43] B. Ranty, D. Aldon, V. Cotelle, J.-P. Galaud, P. Thuleau, C. Mazars, Calcium Sensors as Key Hubs in Plant Responses to Biotic and Abiotic Stresses, Front. Plant Sci. 7 (2016). https://doi.org/10.3389/fpls.2016.00327.

[44] D. Villaseñor, Y. Noblecilla-Romero, E. Luna-Romero, R. Molero-Naveda, S. Barrezueta-Unda, W. Huarquila-Henriquez, C. González-Porras, J. Garzón-Montealegre, Optimal economic response of potassic fertilization on productive variables of banana (Musa spp.)., Chilean Journal of Agricultural \&amp; Animal Sciences, ex Agro-Ciencia. 36 (2020) 161-170. https://www.cabdirect.org/cabdirect/abstract/20203472913 (accessed June 1, 2021).

[45] J.A. Camargo, Á. Alonso, Ecological and toxicological effects of inorganic nitrogen pollution in aquatic ecosystems: A global assessment, Environment International. 32 (2006) 831-849. https://doi.org/10.1016/j.envint.2006.05.002.

[46] P.J. White, Improving potassium acquisition and utilisation by crop plants, Journal of Plant Nutrition and Soil Science. 176 (2013) 305-316. https://doi.org/10.1002/jpln.201200121.

[47] W. Grzebisz, A. Gransee, W. Szczepaniak, J. Diatta, The effects of potassium fertilization on water-use efficiency in crop plants, Journal of Plant Nutrition and Soil Science. 176 (2013) 355-374. https://doi.org/10.1002/jpln.201200287.

[48] T.T. Cochrane, T.A. Cochrane, The vital role of potassium in the osmotic mechanism of stomata aperture modulation and its link with potassium deficiency, Plant Signaling \& Behavior. 4 (2009) 240-243. https://doi.org/10.4161/psb.4.3.7955.

[49] M. Wang, Q. Zheng, Q. Shen, S. Guo, The Critical Role of Potassium in Plant Stress Response, Int J Mol Sci. 14 (2013) 7370-7390. https://doi.org/10.3390/ijms14047370.

[50] J. Pathak, H. Ahmed, N. Kumari, A. Pandey, Rajneesh, R.P. Sinha, Role of Calcium and Potassium in Amelioration of Environmental Stress in Plants, in: Protective Chemical Agents in the Amelioration of Plant Abiotic Stress, John Wiley \& Sons, Ltd, 2020: pp. 535-562. https://doi.org/10.1002/9781119552154.ch27.

[51] O. Shaul, Magnesium transport and function in plants: the tip of the iceberg, Biometals. 15 (2002) 307-321. https://doi.org/10.1023/A:1016091118585. 
[52] J. Bose, O. Babourina, S. Shabala, Z. Rengel, Low-pH and Aluminum Resistance in Arabidopsis Correlates with High Cytosolic Magnesium Content and Increased Magnesium Uptake by Plant Roots, Plant and Cell Physiology. 54 (2013) 1093-1104. https://doi.org/10.1093/pcp/pct064.

[53] A. Rosanoff, C.M. Weaver, R.K. Rude, Suboptimal magnesium status in the United States: are the health consequences underestimated?, Nutrition Reviews. 70 (2012) 153-164. https://doi.org/10.1111/j.1753-4887.2011.00465.x.

[54] C. Hermans, S.J. Conn, J. Chen, Q. Xiao, N. Verbruggen, An update on magnesium homeostasis mechanisms in plants, Metallomics. 5 (2013) 1170-1183. https://doi.org/10.1039/c3mt20223b.

[55] W. Guo, H. Nazim, Z. Liang, D. Yang, Magnesium deficiency in plants: An urgent problem, The Crop Journal. 4 (2016) 83-91. https://doi.org/10.1016/j.cj.2015.11.003.

[56] A. Gransee, H. Führs, Magnesium mobility in soils as a challenge for soil and plant analysis, magnesium fertilization and root uptake under adverse growth conditions, Plant Soil. 368 (2013) 5-21. https://doi.org/10.1007/s11104-012-1567-y.

[57] E. Ciríaco da Silva, R.J. Nogueira, M. Silva, M. Albuquerque, Drought Stress and Plant Nutrition, Plant Stress. 5 (2010) 32-41.

[58] G.K. Kinuthia, V. Ngure, D. Beti, R. Lugalia, A. Wangila, L. Kamau, Levels of heavy metals in wastewater and soil samples from open drainage channels in Nairobi, Kenya: community health implication, Sci Rep. 10 (2020) 8434. https://doi.org/10.1038/s41598-02065359-5.

[59] J. Hrenovic, T. Ivankovic, Survival of Escherichia coli and Acinetobacter junii at various concentrations of sodium chloride, Eurasian Journal of Biosciences. 3 (2009) 144-151. https://doi.org/10.5053/ejobios.2009.3.0.18.

[60] S. Boerlage, Measuring salinity and TDS of seawater and brine for process and environmental monitoring - which one, when?, Desalination and Water Treatment DESALIN WATER TREAT. 42 (2012) 222-230. https://doi.org/10.1080/19443994.2012.683191.

[61] M.A. Dawoud, Environmental Impacts of Seawater Desalination: Arabian Gulf Case Study, International Journal of Environment and Sustainability. 1 (2012). https://doi.org/10.24102/ijes.vli3.96.

[62] M. Ahmed, W.H. Shayya, D. Hoey, J. Al-Handaly, Brine disposal from reverse osmosis desalination plants in Oman and the United Arab Emirates, Desalination. 133 (2001) 135147. https://doi.org/10.1016/S0011-9164(01)80004-7.

[63] M. Ahrned, D. Hoey, M.R. Thumarukudyd, M.F.A. Goosen, M. Al-Haddabi, A. AlBelushi, Feasibility of salt production Corn inland RO desalination plant reject brine: a case study, (n.d.) 9.

[64] N. Skliris, J.D. Zika, L. Herold, S.A. Josey, R. Marsh, Mediterranean sea water budget long-term trend inferred from salinity observations, Clim Dyn. 51 (2018) 2857-2876. https://doi.org/10.1007/s00382-017-4053-7.

[65] D. Gomis, M.N. Tsimplis, B. Martín-Míguez, A.W. Ratsimandresy, J. García-Lafuente, S.A. Josey, Mediterranean Sea level and barotropic flow through the Strait of Gibraltar for the period 1958-2001 and reconstructed since 1659, Journal of Geophysical Research: Oceans. 111 (2006). https://doi.org/10.1029/2005JC003186. 
[66] S. Garcia-Ayllon, The Integrated Territorial Investment (ITI) of the Mar Menor as a model for the future in the comprehensive management of enclosed coastal seas, Ocean \& Coastal Management. 166 (2018) 82-97. https://doi.org/10.1016/j.ocecoaman.2018.05.004.

[67] V.G. Gude, Desalination and sustainability - An appraisal and current perspective, Water Research. 89 (2016) 87-106. https://doi.org/10.1016/j.watres.2015.11.012.

[68] Y. Tramblay, A. Koutroulis, L. Samaniego, S.M. Vicente-Serrano, F. Volaire, A. Boone, M. Le Page, M.C. Llasat, C. Albergel, S. Burak, M. Cailleret, K.C. Kalin, H. Davi, J.-L. Dupuy, P. Greve, M. Grillakis, L. Hanich, L. Jarlan, N. Martin-StPaul, J. Martínez-Vilalta, F. Mouillot, D. Pulido-Velazquez, P. Quintana-Seguí, D. Renard, M. Turco, M. Türkeş, R. Trigo, J.-P. Vidal, A. Vilagrosa, M. Zribi, J. Polcher, Challenges for drought assessment in the Mediterranean region under future climate scenarios, Earth-Science Reviews. 210 (2020) 103348. https://doi.org/10.1016/j.earscirev.2020.103348.

[69] K. Belhassan, Water Scarcity Management, in: A. Vaseashta, C. Maftei (Eds.), Water Safety, Security and Sustainability: Threat Detection and Mitigation, Springer International Publishing, Cham, 2021: pp. 443-462. https://doi.org/10.1007/978-3-030-76008-3_19.

[70] J.A. Aznar-Sánchez, L.J. Belmonte-Ureña, J.F. Velasco-Muñoz, D.L. Valera, Farmers' profiles and behaviours toward desalinated seawater for irrigation: Insights from South-east Spain, Journal of Cleaner Production. 296 (2021) 126568. https://doi.org/10.1016/j.jclepro.2021.126568.

[71] L. Incrocci, N. Colucci, L. Mendoza, M. Guzmán, GreenFert. Gestor de Fertilización del Suelo en invernadero, 2020. https://doi.org/10.13140/RG.2.2.32401.38249.

[72] J.J. Magán, M. Gallardo, R.B. Thompson, P. Lorenzo, Effects of salinity on fruit yield and quality of tomato grown in soil-less culture in greenhouses in Mediterranean climatic conditions, Agricultural Water Management. 95 (2008) 1041-1055. https://doi.org/10.1016/j.agwat.2008.03.011.

[73] Y. Rouphael, S.A. Petropoulos, M. Cardarelli, G. Colla, Salinity as eustressor for enhancing quality of vegetables, Scientia Horticulturae. 234 (2018) 361-369. https://doi.org/10.1016/j.scienta.2018.02.048.

[74] H. Zekki, L. Gauthier, A. Gosselin, Growth, Productivity, and Mineral Composition of Hydroponically Cultivated Greenhouse Tomatoes, with or without Nutrient Solution Recycling, Journal of the American Society for Horticultural Science. 121 (1996) 10821088. https://doi.org/10.21273/JASHS.121.6.1082.

[75] A. Malik, dr khalid Mughal, S. Mian, A. Khan, Hydroponic Tomato Production and Productivity Improvement in Pakistan, Pakistan Journal of Agricultural Research. 31 (2018). https://doi.org/10.17582/journal.pjar/2018/31.2.133.144.

[76] H. March, D. Saurí, A.M. Rico-Amorós, The end of scarcity? Water desalination as the new cornucopia for Mediterranean Spain, Journal of Hydrology. 519 (2014) 2642-2651. https://doi.org/10.1016/j.jhydrol.2014.04.023.

[77] A. Green, S. Bell, Neo-hydraulic water management: an international comparison of idle desalination plants, Null. 16 (2019) 125-135. https://doi.org/10.1080/1573062X.2019.1637003.

[78] M. de las M. Capobianco-Uriarte, J. Aparicio, J.D. Pablo-Valenciano, M. del P. CasadoBelmonte, The European tomato market. An approach by export competitiveness maps, PLOS ONE. 16 (2021) e0250867. https://doi.org/10.1371/journal.pone.0250867.

[79] International Statistics Flowers and Plants, Institut für Gartenbauökonomie der Universität Hannover, 2005. 
[80] N.A. Vélez-Carvajal, S.E. Melo-Martínez, V.J. Flórez-Roncancio, Behavior of Ca, Mg S in a soilless culture system for carnation., Revista Chapingo. Serie Horticultura. 20 (2014) 171-185. https://www.cabdirect.org/cabdirect/abstract/20143319578 (accessed June 6, 2021).

[81] S. Kazaz, S. Yilmaz, B. Sayin, Comparison Of Soil And Soilless Cultivation Of Carnation In Isparta Province, Acta Horticulturae. (2009) 547-552. https://doi.org/10.17660/ActaHortic.2009.807.80.

[82] A. Navarro, A. Elia, G. Conversa, P. Campi, M. Mastrorilli, Potted mycorrhizal carnation plants and saline stress: Growth, quality and nutritional plant responses, Scientia Horticulturae. 140 (2012) 131-139. https://doi.org/10.1016/j.scienta.2012.03.016.

[83] R. Baas, H.M.C. Nijssen, T.J.M. van den Berg, M.G. Warmenhoven, Yield and quality of carnation (Dianthus caryophyllus L.) and gerbera (Gerbera jamesonii L.) in a closed nutrient system as affected by sodium chloride, Scientia Horticulturae. 61 (1995) 273-284. https://doi.org/10.1016/0304-4238(94)00728-X.

[84] A. Pardossi, F. Tognoni, L. Incrocci, Mediterranean greenhouse technology, Chronica Horticulturae. 44 (2004) 28-34.

[85] M.J. López-Serrano, J.F. Velasco-Muñoz, J.A. Aznar-Sánchez, I.M. Román-Sánchez, Economic Analysis of the Use of Reclaimed Water in Agriculture in Southeastern Spain, A Mediterranean Region, Agronomy. 11 (2021) 2218. https://doi.org/10.3390/agronomy11112218.

[86] S. Engindeniz, Economic analysis of processing tomato growing: The case study of Torbali, west Turkey, SPANISH JOURNAL OF AGRICULTURAL RESEARCH. 5 (2007). https://doi.org/10.5424/sjar/2007051-218.

[87] F.D. Molina-Aiz, D.L. Valera, A. López, R. Bouharroud, H. Fatnassi, Analysis of economic sustainability of tomato greenhouses in Almería (Spain), Acta Hortic. (2020) 1169-1177. https://doi.org/10.17660/ActaHortic.2020.1296.148.

[88] C. M, A. Yadav, Water desalination system using solar heat: A review, Renewable and Sustainable Energy Reviews. 67 (2017) 1308-1330. https://doi.org/10.1016/j.rser.2016.08.058.

[89] V.P. Katekar, S.S. Deshmukh, Techno-economic review of solar distillation systems: A closer look at the recent developments for commercialisation, Journal of Cleaner Production. 294 (2021) 126289. https://doi.org/10.1016/j.jclepro.2021.126289.

[90] N. Xu, J. Li, Y. Wang, C. Fang, X. Li, Y. Wang, L. Zhou, B. Zhu, Z. Wu, S. Zhu, J. Zhu, A water lily-inspired hierarchical design for stable and efficient solar evaporation of highsalinity brine, Science Advances. (2019). https://doi.org/10.1126/sciadv.aaw7013.

[91] C.T.K. Finnerty, A.K. Menon, K.M. Conway, D. Lee, M. Nelson, J.J. Urban, D. Sedlak, B. Mi, Interfacial Solar Evaporation by a 3D Graphene Oxide Stalk for Highly Concentrated Brine Treatment, Environ. Sci. Technol. 55 (2021) 15435-15445. https://doi.org/10.1021/acs.est.1c04010.

[92] Y.-Q. Luo, F. Song, J.-M. Wu, F. Wang, X.-L. Wang, Y.-Z. Wang, A nature-inspired suspended solar evaporator for water desalination of high-salinity brines, Chemical Engineering Journal. 421 (2021) 129824. https://doi.org/10.1016/j.cej.2021.129824.

[93] Y. Xia, Q. Hou, H. Jubaer, Y. Li, Y. Kang, S. Yuan, H. Liu, M. Wai Woo, L. Zhang, L. Gao, H. Wang, X. Zhang, Spatially isolating salt crystallisation from water evaporation for continuous solar steam generation and salt harvesting, Energy \& Environmental Science. 12 (2019) 1840-1847. https://doi.org/10.1039/C9EE00692C. 
[94] Aqua Abib - Solar distillation for affordable water and solute recovery, (n.d.). https://www.aqua-abib.com/ (accessed September 7, 2021).

[95] D. Borge-Diez, F.J. García-Moya, P. Cabrera-Santana, E. Rosales-Asensio, Feasibility analysis of wind and solar powered desalination plants: An application to islands, Science of The Total Environment. 764 (2021) 142878. https://doi.org/10.1016/j.scitotenv.2020.142878.

[96] D.G. Randall, J. Nathoo, Resource recovery by freezing: A thermodynamic comparison between a reverse osmosis brine, seawater and stored urine, Journal of Water Process Engineering. 26 (2018) 242-249. https://doi.org/10.1016/j.jwpe.2018.10.020.

[97] H. Dong, C. Unluer, E.-H. Yang, A. Al-Tabbaa, Recovery of reactive $\mathrm{MgO}$ from reject brine via the addition of NaOH, Desalination. 429 (2018) 88-95. https://doi.org/10.1016/j.desal.2017.12.021.

[98] D.H. Kim, A review of desalting process techniques and economic analysis of the recovery of salts from retentates, Desalination. 270 (2011) 1-8. 